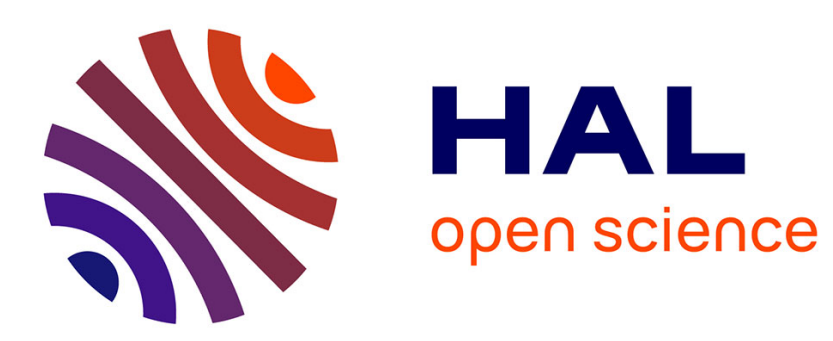

\title{
Hypoxic dose, intensity distribution, and fatigue monitoring are paramount for "live high-train low" effectiveness
}

Franck Brocherie, L. Schmitt, Grégoire P. Millet

\section{- To cite this version:}

Franck Brocherie, L. Schmitt, Grégoire P. Millet. Hypoxic dose, intensity distribution, and fatigue monitoring are paramount for "live high-train low" effectiveness. European Journal of Applied Physiology, 2017. hal-02108661

\section{HAL Id: hal-02108661 https: / hal-insep.archives-ouvertes.fr/hal-02108661}

Submitted on 24 Apr 2019

HAL is a multi-disciplinary open access archive for the deposit and dissemination of scientific research documents, whether they are published or not. The documents may come from teaching and research institutions in France or abroad, or from public or private research centers.
L'archive ouverte pluridisciplinaire HAL, est destinée au dépôt et à la diffusion de documents scientifiques de niveau recherche, publiés ou non, émanant des établissements d'enseignement et de recherche français ou étrangers, des laboratoires publics ou privés. 


\section{Hypoxic dose, intensity distribution, and fatigue monitoring are paramount for "live high-train low" effectiveness}

Franck Brocherie, 1 四

Phone $+33(0) 141744354$

Email franck.brocherie@insep.fr

L. Schmitt, 2

G. P. Millet, 3

${ }^{1}$ Laboratory Sport, Expertise and Performance (EA 7370), Research Department, French Institute of Sport (INSEP), 11 Avenue du Tremblay, Paris, France

${ }^{2}$ National Ski-Nordic Center, Premanon, Les Rousses, France

3 Institute of Sports Sciences (ISSUL), University of Lausanne, Lausanne, Switzerland

Communicated by Westerterp/Westerblad.

This article is a comment on: Endurance, aerobic high-intensity, and repeated sprint cycling performance is unaffected by normobaric "Live High-Train Low": a double-blind placebo-controlled cross-over study, by Bejder J, Andersen AB, Buchardt R, Larsson TH, Olsen NV, Nordsborg NB. Eur J Appl Physiol (2017) 117:979-988. AQ1

We read with attention the article by Bejder et al. (2017). While we acknowledge the good intent of the authors to carefully follow scientific gold-standard design of a double-blind, placebo-controlled, cross-over trial, we were disappointed that the general recommendations (i.e., $>12 \mathrm{~h} \mathrm{day}^{-1}$ at simulated altitude ranging 2000-2500 m for 3-4 weeks) 
for "live high-train low" (LHTL) altitude strategy (Chapman et al. 2014) were not respected. Subsequently, one may have been surprised to observe any LHTL putative effects. Even though Bejder et al. (2017) extensively discuss several potential limitations (see Methodological considerations section), several other boundaries (i.e., unsuitable hypoxic dose, normobaric hypoxic tent discomfort, inadequate training intensity distribution) may have, alone or in combination, altered the outcomes of their study.

AQ2

AQ3

To compensate the restricted low daily hypoxic dose (i.e., $8 \mathrm{~h} \mathrm{day}^{-1}$ ) due to the use of normobaric hypoxic tents, Bejder et al. (2017) extended the duration of intervention (i.e., 6 weeks) and increased the altitude level (i.e., $3 \times 2$ weeks at 2500, 3000, and $3500 \mathrm{~m}$, respectively), resulting to a total hypoxic dose of $336 \mathrm{~h}$ (or $1008 \mathrm{~km} \mathrm{~h}^{-1}$ using the new $\mathrm{km} \mathrm{h}^{-1}$ hypoxic metrics) expected to induce the erythropoietic cascade and improve exercise performance. However, it seems that hypoxic severity and/or intervention duration were inadequate. For instance, hypoxic stress $>3000 \mathrm{~m}$ was suggested to be detrimental to acclimatization (Brugniaux et al. 2006) and sea-level performance enhancement (Chapman et al. 2014). The most likely explanation relates to an accumulated influence of negative factors. In particular, the use of the (commercially available) normobaric hypoxic tent could have contributed to respiratory disturbance, with increases in sleep apneas (Pedlar et al. 2005), via an accumulation of expired carbon dioxide $\left(\mathrm{CO}_{2}\right)$, as well as a rise in temperature and humidity inside the tent. Alone or in combination with the hypoxic stress, hypercapnia might have induced neurocognitive deficits (i.e., acute changes in cerebral blood flow, $\mathrm{pH}$, catecholamine, and neuronal excitability) and depression in cortical electrical activity, related to endocrine and cardiovascular alterations (see viewpoint and comments from Wang et al. 2016). Therefore, when using such low air volume material, $\mathrm{CO}_{2}$ monitoring must be encouraged (in addition to desaturation-level control, which was not the case in Bejder et al. 2017). While the longterm health implications of sleep apneas in athletes remain unknown, inadequate restorative process between training sessions may lead to symptoms of overreaching or overtraining (Pedlar et al. 2005). 
Regarding training intensity distribution, careful analysis of weekly average time spent at low, moderate, and high intensities during sportspecific training (see Table 1 in Bejder et al. 2017) indicates an inadequate balance when compared to the current practice in endurance sports (Tonnessen et al. 2014): with an averaged total training time of $\sim 16-20$ h per week for supposed highly trained triathletes (body weight of $\sim 80 \mathrm{~kg}$ ), approximately half of the time was allocated for moderate(i.e., $\sim 33-34 \%$ ) and high-intensity (i.e., $\sim 12-13 \%$ ) training, respectively. Such training intensity distribution differs from the polarized training model (i.e., $\sim 75-80 \%$ at low intensity, $\sim 5-10 \%$ at moderate intensity, and $\sim 15-20 \%$ at high intensity) generally adopted by endurance athletes and may have participated to inappropriate level of training stress (Tonnessen et al. 2014). The lack of fatigue monitoring as recommended with elite athletes (Schmitt et al. 2015) could explain the slightly reduced maximum physical capacity (i.e., incremental peak power output measured after LHTL intervention). Therefore, to secure optimal adaptation and counteract unwanted side effects such as overreaching/overtraining symptoms, cautious training loads monitoring should be implemented.

Hence, while it seems difficult to decipher on the effectiveness of LHTL paradigm in the study by Bejder et al. (2017), it is clearly evident that the selection of basic components such as appropriate hypoxic dose and proper training load and fatigue management appear paramount to success with LHTL's method.

\section{References}

Bejder J, Andersen AB, Buchardt R, Larsson TH, Olsen NV, Nordsborg NB (2017) Endurance, aerobic high-intensity, and repeated sprint cycling performance is unaffected by normobaric "Live High-Train Low": a double-blind placebo-controlled crossover study. Eur J Appl Physiol 117:979-988

Brugniaux JV, Schmitt L, Robach P, Jeanvoine H, Zimmermann H, Nicolet G, Duvallet A, Fouillot JP, Richalet JP (2006) Living high- 
training low: tolerance and acclimatization in elite endurance athletes. Eur J Appl Physiol 96:66-77

Chapman RF, Karlsen T, Resaland GK, Ge RL, Harber MP, Witkowski S, Stray-Gundersen J, Levine BD (2014) Defining the "dose" of altitude training: how high to live for optimal sea level performance enhancement. J Appl Physiol 116:595-603

Pedlar C, Whyte G, Emegbo S, Stanley N, Hindmarch I, Godfrey R (2005) Acute sleep responses in a normobaric hypoxic tent. Med Sci Sports Exerc 37:1075-1079

Schmitt L, Regnard J, Parmentier AL, Mauny F, Mourot L, Coulmy N, Millet GP (2015) Typology of "fatigue" by heart rate variability analysis in elite nordic-skiers. Int J Sports Med 36:999-1007

Tonnessen E, Sylta O, Haugen TA, Hem E, Svendsen IS, Seiler S (2014) The road to gold: training and peaking characteristics in the year prior to a gold medal endurance performance. PLoS One 9:e101796

Wang D, Thomas RJ, Yee BJ, Grunstein RR (2016) Hypercapnia is more important than hypoxia in the neuro-outcomes of sleepdisordered breathing. J Appl Physiol 120:1484 